DOI https://doi.org/10.30929/2307-9770.2019.07.01.06

UDC 378.013.42:330.1-057.87

\title{
Forming polycultural competence for future economists
}

\author{
Poyasok T., Bespartochna O.* \\ Kremenchuk Mikhailo Ostrogradskyi National University, Kremenchuk, Ukraine
}

Received: $10.03 .2019 \quad$ Accepted: 26.03 .2019

\begin{abstract}
Actuality of the introduction principles of multiculturalism in the system of higher economic education is proved; it was found that multicultural competence of future economists involves getting acquainted with distinctive ethnic national traits in the culture of different peoples; involvement of students in world culture; the disclosure of the process of globalization, interdependence of countries and peoples in modern conditions; recognition of equal rights and obligations of representatives of other peoples and religions; formation of multicultural competences within professional competence; content and directions of formation of multicultural competence are determined; It is proved that polycultural education should be based on the principles of mutual recognition, cooperation, critical pluralism, which will promote the formation of multicultural competences, which will allow graduates of higher education institutions of economic orientation to integrate into space of intercultural dialogue with representatives of different nations. Creation of a multicultural educational environment should be based on a person-oriented paradigm; cognitive, affective, valeological and creative educational practices; strengthening of the ethno-cultural aspect in the content of education, its professional orientation; implementation of the principles of humanization, multiculturalism, continuity, individualization and activity development. The following components of multicultural education as polycultural tolerance and socio-cultural identity, which are considered in the cognitive, emotional-value, and behavioral-activity aspects, are singled out; defined sequence of pedagogical actions in the formation of multicultural competence; pedagogical conditions of effectiveness of formation of multicultural competence are formulated: to provide students with knowledge about contact subcultures, as well as peculiarities of own culture; creation of conditions for emotional perception of multicultural situations; formation of adequate behavior on the basis of multicultural tolerance of future economists (creation of a developing multicultural educational environment; application of interactive methods of multicultural education; activation of creativity and research activity); ways of their implementation are presented; the stages of formation of multicultural competence of students of the economic profile are defined: motivational, cognitive, final.
\end{abstract}

Key words: polycultural competence, future economists, intercultural interaction, multicultural environment, multicultural pedagogy.

\section{Формування полікультурної компетентності майбутніх економістів}

\author{
Поясок Т. Б., Беспарточна О. І. \\ Кременчуцький національний університет імені Михайла Остроградського, Кременчук, Україна
}

\begin{abstract}
Анотація. Доведено актуальність запровадження засад полікультурності в системі вищої економічної освіти; з'ясовано що полікультурна компетентність майбутніх економістів передбачає знайомство 3 самобутніми етнічними національними рисами в культурі різних народів; залучення студентів до світової культури; розкриття процесу глобалізації, взаємозалежності країн і народів у сучасних умовах; визнання рівних прав і обов'язків представників інших народів та релігій; формування полікультурних компетенцій у межах їх профресійної компетентності; визначено зміст та напрями формування полікультурної компетентності; доведено, що полікультурна освіта повинна ґрунтуватись на принципах взаємного визнання, співробітництва, критичного плюралізму, що сприятиме формуванню полікультурної компетентності, яка дозволить випускникам закладів вищої освіти економічного спрямування інтегруватись у простір міжкультурного діалогу з представниками різних націй. Створення полікультурного освітнього середовища повинно здійснюватися на підгрунті особистісно-орієнтованої парадигми; когнітивної, афективної, валеологічної та креативної освітніх практик; посилення етнокультурного аспекту в змісті освіти, його професійної спрямованості; реалізації принципів гуманізації, полікультурності, наступності, індивідуалізації та діяльнісного розвитку. Виокремлено
\end{abstract}

Corresponding Author:

Відповідальний автор:
Bespartochna Olena Ivanivna,Tel. +38(067) 798-05-39. E-mail: bespartochnay@ukr.net vul.Pershotravneva, 20, Kremenchuk, Poltava Region, Ukraine, 39600.

Беспарточна Олена Іванівна.Тел. +38(067) 798-05-39. E-mail: bespartochnay@ukr.net вул. Першотравнева, 20, м. Кременчук Полтавської обл., Україна, 39600. 
такі компоненти полікультурної освіти як полікультурна толерантність та соціокультурна ідентичність, які розглядаються у когнітивному, емоційно-ціннісному та поведінково-діяльнісному аспектах; визначена послідовність педагогічних дій при формування полікультурної компетентності; сфрормульовано педагогічні умови ефективності формування полікультурної компетентності: надання студентам знань щодо контактних субкультур, а також особливостей власної культури; створення умов для емоційного сприйняття полікультурних ситуацій; формування адекватної поведінки на підґрунті полікультурної толерантності майбутніх економістів (створення розвивального полікультурного освітнього середовища; застосування інтерактивних методів полікультурної освіти; активізація креативності і дослідницької діяльності) та представлено шляхи їх реалізації; визначено етапи формування полікультурної компетентності студентів економічного профілю: мотиваційний, пізнавальний, підсумковий.

Ключові слова:полікультурна компетентність, майбутні економісти, міжкультурна взаємодія, полікультурне середовище, полікультурна педагогіка.

\title{
Формирование поликультурной компетентности будущих экономистов
}

\author{
Поясок Т. Б., Беспарточная Е. И.
}

\author{
Кременчугский национальный университет имени Михаила Остроградского, Кременчуг, Украина
}

\begin{abstract}
Аннотация. Доказана актуальность внедрения основ поликультурности в системе высшего экономического образования, выявлено что, поликультурная компетентность будущих экономистов предусматривает знакомство с самобытными этническими национальными чертами в культуре разных народов; привлечение студентов к мировой культуре; раскрытие процесса глобализации, взаимозависимости стран и народов в современных условиях; определение равных прав и обязанностей представите лей других народов и религий; формирование поликультурных компетенций у рамках их профессиональной компетенции; определено содержание и направления формирования поликультурной компетентности; доказано что поликультурное образование должно грунтоваться на принципах взаимного признания, сотрудничества, критического плюрализма, что способствует формированию поликультурной компетенции, которая позволит выпускникам учебных заведений высшего образования экономического направления интегрироваться в пространство межкультурного диалога с представителями разных наций. Создание поликультурной образовательной среды должно происходить на основании личностно-ориентированной парадигмы; когнитивной, аффективной, валеологической и креативных образовательных практик; усиление этнокультурного аспекта в содержании образования, его профессионального направления; реализация принципов гуманизации, поликультурности, последовательности, индивидуализации и деятельносного развития. Выделены такие её компоненты как поликультурная толерантность и социокультурная идентичность, которые рассматриваются в когнитивном, эмоционально-ценностном и поведенческодеятельном аспектах; определена последовательность педагогических действий при формировании поликультурной компетентности; сформулированы педагогические условия эффективности формирования поликультурной компетентности: предоставление студентам знаний относительно контактных субкультур и особенностей собственной культуры; создание условий для эмоционального восприятия поликультурных ситуаций; формирование адекватного поведения на основе поликультурной толерантности; будущих экономистов (создание развивающей поликультурной образовательной среды; использование интерактивных методов поликультурного образования; активизация креативности и исследовательской деятельности) и представлены пути их реализации; определены этапы формирования поликультурной компетентности студентов экономического профиля: мотивационный, познавательный, итоговый.
\end{abstract}

Ключевые слова: поликультурная компетентность, будущие экономисты, межкультурное взаимодействие, поликультурная среда, поликультурная педагогика.

\section{Bcmyn}

Сучасна соціально-економічна ситуація у суспільстві висуває нові вимоги до особистості майбутнього економіста і його фахових якостей. Активні процеси глобалізації зумовили суттєві перетворення в усіх сферах життя людства, зокрема і в економічній. «Фахівці, які отримали вищу економічну освіту, повинні вміти розв'язувати як типові завдання у процесі здійснення виробничих функцій, так і типові проблеми і завдання соціальної діяльності» [11, с. 66]. Оскільки невід'ємною умовою розвитку ринкової економіки та стабільної демократизації $є$ забезпечення прав національнокультурних меншин, зокрема, мовних та освітніх прав,без запровадження засад полікультурності в системі вищої економічної освіти України неможлива і повноцінна інтеграція країни у європейський та світовий освітній простір. За таких умов важливою є проблема формування особистісних професійно 
значущих якостей майбутнього економіста, який володіє не лише професійно необхідними компетенціями, а й має високий рівень комунікативної компетентності, є людиною полікультурною. Підтвердженням важливості полікультурної освіти є поява нових парадигм освіти, входження в науковий обіг таких понять як освітній простір і освітній регіон, полікультурне освітнє середовище та освітні технології, полікультурна педагогіка тощо [4]. Важливою передумовою полікультурної економічної освіти $€$ розвиток в Україні демократичного суспільства, що передбачає відкритість до інших країн, народів і культур; прагнення України до інтеграції в світове і європейське соціально-культурне, соціальноекономічне й освітнє середовище при збереженні національної самобутності. Тому заклади освіти економічного профрілю повинні забезпечити таку освіту, яка б, з одного боку, допомагала представникам різних культур співпрацювати на основі гармонійної взаємодії, а з іншого - озброїла майбутніх фахівців з економіки знаннями і вміннями жити в демократичному суспільстві [10].

Проблеми професійної підготовки майбутніх економістів досліджували О. Набока[7], Т. Поясок [11], В.Різник [12], Н. Ткаленко [14] та ін. Дослідженню проблем полікультурності в освіті присвячені праці І. Соколової [13], М. Лук'янової [6], Л. Шустової [6], В. Кузьменко [5] та ін. Але на формуванні полікультурної компетентності майбутніх економістів увага науковців не зосереджувалась.

Метою cmammi $€$ дослідження особливостей формування полікультурної компетентності майбутніх фахівців з економіки.

\section{II Матеріал і методи дослідження}

Проблеми полікультурності доцільно розглядати в контексті феномену культури. Залежно від підходу до вивчення, це поняття включає різні аспекти. Ми послуговувались визначенням, сформульованим В.М.Гриньовою, яка розглядає феномен культури як специфічно людський спосіб буття, який визначає весь спектр практичної та духовно активної людини, її можливої взаємодії 3 навколишнім світом із собою [2]. Отже, всі культурні цінності $є$ результатом відображення практичної діяльності людини, тому знаходяться у тісному взаємозв'язку. Полікультурність $є$ характеристикою суспільства з різноманітними, але взаємозалежними культурними традиціями. В Україні наявне полікультурне середовище, а співіснування різноетнічних груп у певних соціальних умовах протягом століть сприяло напрацюванню соціального досвіду певних форм взаємин. Оскільки сьогодні українське суспільство також об'єднує людей різних національностей з усіма формами взаємодії та взаємовпливів, у сучасній педагогіці вищої школи домінуючим повинен бути культурологічний підхід, який орієнтує освіту на діалог з культурою людини як її творця та суб'єкта, здатного до культурного саморозвитку [5].

Полікультурна освіта забезпечує усвідомлення ролі особистості як представника певної національності в збереженні й розвитку культури цієї нації. «Сучасність потребує створення нового типу працівника, який поєднав би в собі високий професіоналізм, мобільність у зміні роботи та високу соціальну відповідальність» [7]. Провідною метою в економічних закладах вищої освіти є формування необхідних компетенцій, які сприяють успішному функціонуванню особистості в регіональній загальнонаціональній та світовій культурах. Полікультурність економічної освіти повинна забезпечувати таке навчання, яке спрямоване безпосередньо на розвиток особистості, її самоорганізацію; акцентувати увагу не на обсязі знань, а на особистісному зростанні студентів. Тому необхідна перебудова навчального процесу, трансформація навчального плану підготовки економістів з точки зору різних культур [10]. Поряд з цим, культура є змінним процесом, що залежить від індивіда, місця і часу. Кожна група людей, нація створює свій стиль життя зі своїми цінностями, нормами, поведінкою [16]. Міжкультурна комунікація $є$ засобом культурної експансії. В той же час комунікація у полікультурному середовищі потребує спеціальних знань і навичок реалізації комунікативних задач.

Сучасні науковці шукають шляхи вирішення проблем міжкультурної взаємодії. У межах полікультурного навчання С. Бахман, Г. Весслінг, С. Герхолл запропонували спрямовану на розвиток пізнавальних процесів та аналіз культур систему вправ, яка, залежно від зорієнтованості, поділена на чотири групи:

1) розвиток міжкультурної поінформованості та сприйняття (коментування сприйнятого, розповідь за малюнком, опис за шаблоном, оцінка ситуації);

2) висловлювання думки (продовження розповіді, знаходження антонімів та синонімів, виокремлення невідповідних змісту слів, робота у проектних групах); 
3) порівняння культур (знаходження спільного і відмінного у культурах, порівняння стереотипів та соціально-культурних компонентів);

4) формування комунікативної компетентності в ситуації міжкультурного спілкування (рольові ігри, дискусії, переказ) [15].

Л. Палмарчук наголошує, що гармонійне функціонування полікультурного соціуму можливе за умови виховання його громадян у системі загальнолюдських цінностей і пріоритетів, серед яких найважливішими $€$ глибинне і всебічне опанування власної культури, вироблення толерантного ставлення, розвиток умінь і навичок продуктивної взаємодії з представниками інших культур. Успішність реалізації виховних завдань залежить від рівня полікультурної компетентності педагогічних працівників, яка, будучи інтегральним утворенням, залежить від сформованості окремих компетенцій[9].

В. Давидов зазначає, що оптимальна освітня стратегія можлива лише за умови поєднання принципів монокультурності та полікультурності, їх взаємокорекції та рівноваги. Такою стратегією $€$ діалог. Тому супермету сучасної освіти можна визначити як виховання діалогічної людини, здатної сприймати і створювати світ у гармонії його різноманітності. Діалог носіїв різних культур в багатоманітному освітньому просторі дозволяє усвідомити необхідність керуватись у своїй діяльності гуманними мотивами [3].

Одним з головних засобів формування полікультурної компетентності $€$ відповідне вивчення навчальних дисциплін. В. Борисенков вважає, що наявність полікультурної компоненти в навчальних дисциплінах дозволяє вирішувати подвійну задачу: стимулювати інтерес студентів до нового знання і одночасно пропонувати різні точки зору на оточуючий світ [1].

Полікультурна освіта і виховання багатодисциплінарні, оскільки при їх реалізації вивчається широкий спектр дисциплін гуманітарного, естетичного, природничого циклів. У дослідженні Л. Новікової визначено три основних підходи до побудови полікультурної освіти: з позицій культурної асиміляції, плюралістичний та критичний [8].

Полікультурна освіта повинна ґрунтуватись на принципах взаємного визнання, співробітництва, критичного плюралізму, що сприятиме формуванню полікультурної компетентності, яка дозволить випускникам закладів вищої освіти економічного спрямування інтегруватись у простір міжкультурного діалогу з представниками різних націй. Створення полікультурного освітнього середовища повинно здійснюватися на підґрунті особистісно-орієнтованої парадигми; когнітивної, афективної, валеологічної та креативної освітніх практик; посилення етнокультурного аспекту в змісті освіти, його професійної спрямованості; реалізації принципів гуманізації, полікультурності, наступності, індивідуалізації та діяльнісного розвитку.

\section{III Результати}

Оскільки особистість формується під впливом культури, ідентичність у полікультурному розумінні являє собою самоототожнювання з певною культурою, з прийнятими у певній культурі нормами і формами поведінки. Для забезпечення ефективної комунікативної поведінки майбутнього економіста у полікультурному середовищі необхідне опанування ним полікультурної грамотності, складовими якої є: здатність зрозуміти звичаї і традиції, норми і цінності іншої культури; знання про іншу культуру; здатність визнавати об'єктивність відмінностей світогляду у різних людей; визнання унікальності кожної культури. Формування полікультурної компетентності повинно здійснюватися у таких напрямах, як: інформаційна насиченість, емоційний вплив і поведінкові норми, що зображено на рис. 1.

Формування полікультурної компетентності повинне ґрунтуватись на розумінні її сутності, яку ми визначаємо як інтегративну якість особистості, яка відображає розуміння змісту, засобів і способів взаємодії з іншими культурами, що реалізується у здатності орієнтуватись у полікультурному середовищі, розуміти його цінності, втілюючи їх у гідній цивілізованій поведінці в процесі позитивної взаємодії з представниками різних культур. Зміст полікультурної компетентності складають знання, уміння і ставлення, що відображено у таблиці 1. 


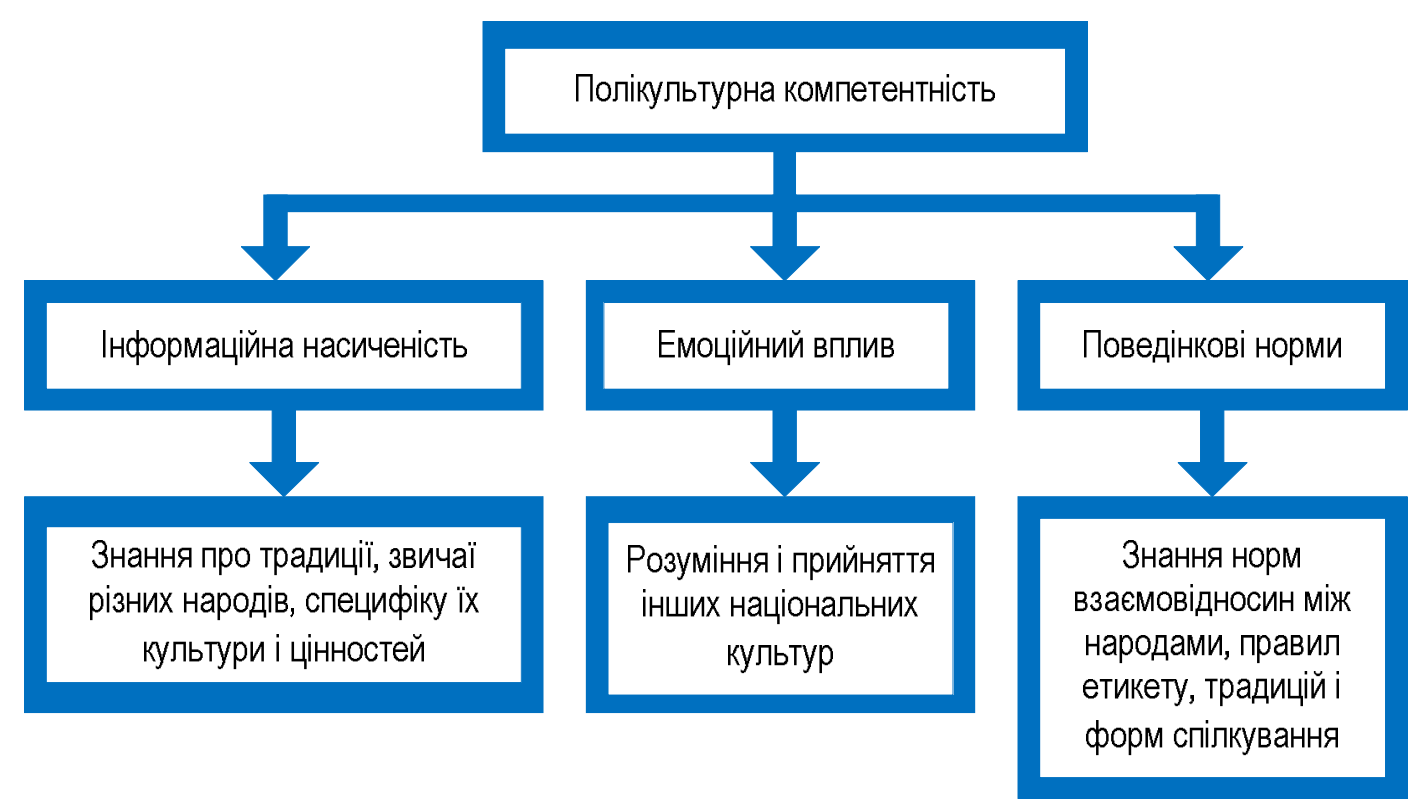

Рис. 1. Напрями формування полікультурної компетентності

Табл. 1. Зміст полікультурної компетентності

\begin{tabular}{|c|c|c|}
\hline $\begin{array}{l}\text { № } \\
3 / \pi\end{array}$ & $\begin{array}{c}\text { Складові } \\
\text { змісту }\end{array}$ & Змістове наповнення \\
\hline 1 & Знання & $\begin{array}{l}\text { Знання основних категорій полікультурності, зміст яких зосереджено на культурі, } \\
\text { багатокультурності; знання про расизм і дискримінацію; засвоєння сутності привілеїв } \\
\text { і упереджень; знання основ толерантності, солідарності; прийняття інших носіїв } \\
\text { культури }\end{array}$ \\
\hline 2 & Уміння & $\begin{array}{l}\text { Уміння бачити відмінності і схожість між культурами, наводити приклади, що } \\
\text { підтверджують їх; уміння інтерпретувати іншу культуру (ї̈ символи, традиції, стиль } \\
\text { одягу тощо), переводити ці символи в мовний опис культури; уміння застосовувати } \\
\text { схему характеристики своєї культури відносно іншої і при цьому бачити зв'язок між } \\
\text { своєю та іншою культурою; уміння демонструвати толерантність, показувати і } \\
\text { визначати негативні стереотипи і надузагальнення у засобах масової інформації, у } \\
\text { поведінці; вміння пояснювати природу будь-якої іншої групи, планувати свою } \\
\text { поведінку в середовищі іншої культури }\end{array}$ \\
\hline 3 & Ставлення & $\begin{array}{l}\text { Формування власних суджень щодо проявів неповаги, дискримінації представників } \\
\text { іншої культури; критичне сприймання анекдотів на етнічні теми; вироблення власних } \\
\text { критеріїв полікультурної поведінки; оцінювання вчинків людей через призму } \\
\text { багатокультурності }\end{array}$ \\
\hline
\end{tabular}

\section{IV Обговорення}

Отже, зміст полікультурної компетентності - це сукупність знань, умінь та суджень, які сприяють засвоєнню студентами знань про культуру різних народів, уявлень про багатоманітність культур; умінь і навичок продуктивної взаємодії з носіями інших культур; набір певних знань і умінь у галузі міжкультурного спілкування.

Для формування полікультурної компетентності майбутніх економістів необхідна організація полікультурного освітнього середовища; залучення студентів до різних культур; навчання спілкуванню, заснованому на взаєморозумінні і взаємоповазі; знанні етнічних особливостей, етики, традицій різних народів.

Полікультурна компетентність майбутніх економістів складається з таких взаємопов'язаних компонентів як полікультурна толерантність і соціокультурна ідентичність, які розглядаються в 
когнітивному, емоційно-ціннісному та поведінково-діяльнісному аспектах, що схематично зображено на рис. 2.

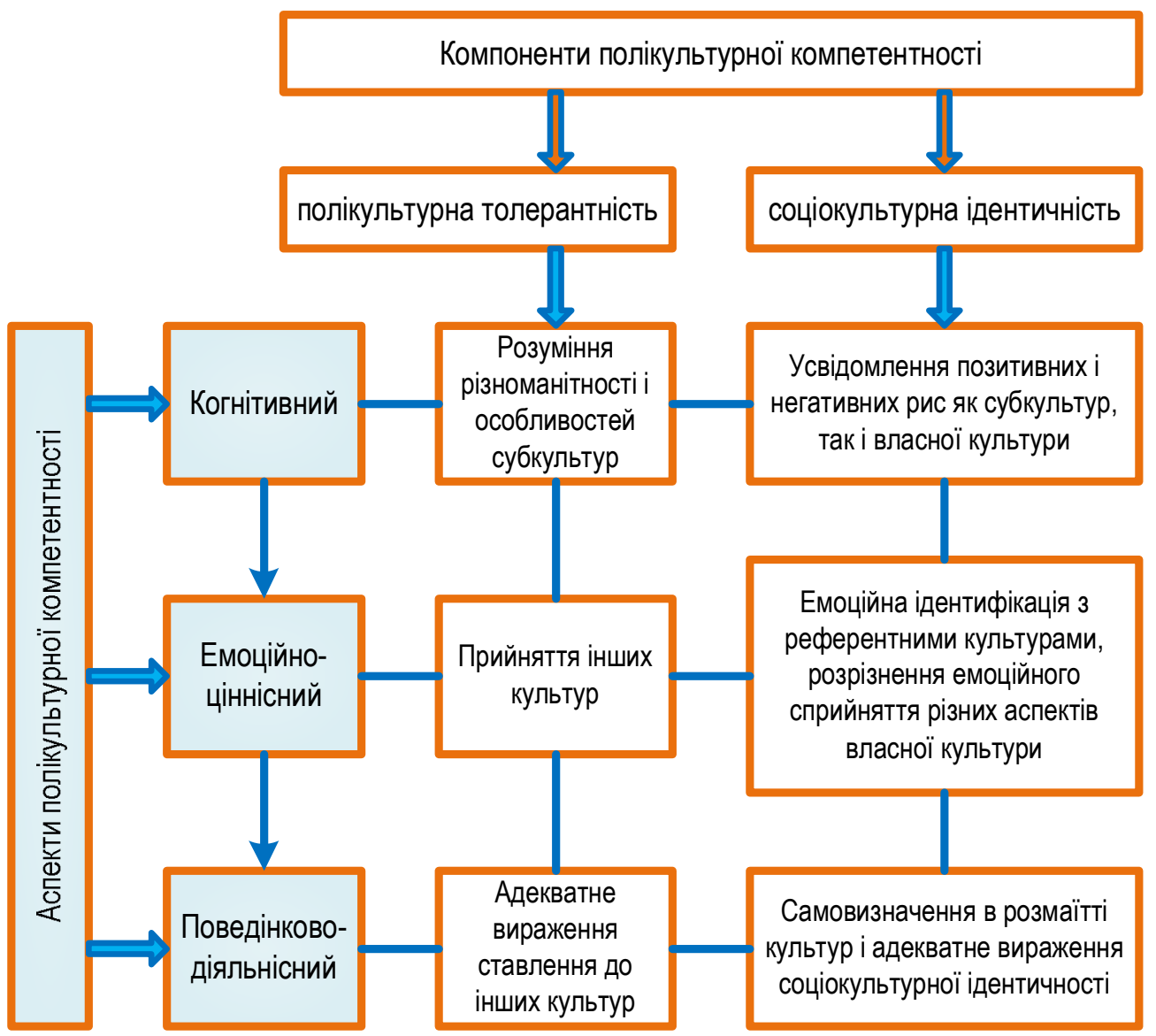

Рис. 2. Складові полікультурної компетентності

Визначені аспекти розгляду компонентів полікультурної компетентності відображають послідовність її формування. Відповідною повинна бути і послідовність педагогічних дій, а саме:

1) надання студентам знань щодо контактних субкультур, а також особливостей власної культури;

2) створення умов для емоційного сприйняття полікультурних ситуацій;

3) формування адекватної поведінки на підгрунті полікультурної толерантності.

Ефективність формування полікультурної компетентності майбутніх економістів забезпечується наступними педагогічними умовами:

- створення розвивального полікультурного середовища;

- застосування інтерактивних методів полікультурної освіти;

- активізація креативності і дослідницької діяльності студентів.

Шляхи реалізації зазначених умов подані в таблиці 2.

Одним із засобів формування полікультурної компетентності майбутніх економістів $\epsilon$ забезпечення культурологічної спрямованості їх професійної підготовки, яка передбачає толерантність; розуміння і повагу інших народів, іншої культури, цивілізації, життєвих цінностей; відкритість і готовність до відкритого міжкультурного спілкування; усвідомлення необхідності взаєморозуміння між людьми і народами; соціокультурна ідентифрікація. При цьому важливо, щоб у навчальному матеріалі відображались гуманістичні ідеї; надавалась характеристика унікальних самобутніх рис у культурах народів світу; розкривались у культурах народів спільні елементи традицій, які дозволяють мирно співіснувати; розкривались процеси глобалізації, взаємозалежності країн і народів світу в сучасних умовах. 
Табл. 2. Реалізація педагогічних умов формування полікультурної компетентності майбутніх економістів

\begin{tabular}{|c|c|c|}
\hline $\begin{array}{l}\text { № } \\
3 / \text { }\end{array}$ & Педагогічна умова & Шляхи реалізації \\
\hline 1 & $\begin{array}{l}\text { створення } \\
\text { розвивального } \\
\text { полікультурного } \\
\text { середовища }\end{array}$ & $\begin{array}{l}\text { реалізація розвивальних програм полікультурної спрямованості; } \\
\text { створення психологічної атмосфрери взаємоповаги між студентами, } \\
\text { їх позитивної мотивації до формування полікультурності }\end{array}$ \\
\hline 2 & $\begin{array}{l}\text { застосування } \\
\text { інтерактивних } \\
\text { методів } \\
\text { полікультурної освіти }\end{array}$ & $\begin{array}{l}\text { впровадження в освітній процес дискусій, розмірковувань, дебатів, } \\
\text { круглих столів, проективної діяльності, активного слухання, ділових } \\
\text { ігор, мозкового штурму, тренінгів, моделювання та аналізу ситуацій } \\
\text { міжкультурної взаємодії }\end{array}$ \\
\hline 3 & $\begin{array}{l}\text { активізація } \\
\text { креативності і } \\
\text { дослідницької } \\
\text { діяльності студентів }\end{array}$ & $\begin{array}{l}\text { застосування творчих методів навчання; залучення до виконання } \\
\text { дослідницьких проектів; спонукання до самостійного визначення } \\
\text { проблем, які виникають у полікультурному суспільстві та пошуку їх } \\
\text { вирішення; здійснення студентами самоідентифікації }\end{array}$ \\
\hline
\end{tabular}

Формування полікультурної компетентності майбутніх економістів доцільно здійснювати в три етапи: мотиваційний, пізнавальний, підсумковий. Метою мотиваційного етапу $є$ створення позитивного емоційного налаштування на такі загальнолюдські цінності як терпимість, звичаї і традиції різних народів, віросповідання, права людини тощо. Це допоможе створити певне налаштування і скоригувати роботу відповідно особливостей аудиторії. Пізнавальний етап передбачає наступні напрями: знайомство студентів із загальнолюдськими цінностями; критичний аналіз майбутніми економістами матеріалів засобів масової інформації, інформаційних ресурсів мережі Інтернет, які показують реальні етнічні процеси і розглядають можливі шляхи їх вирішення з точки зору загальнолюдських цінностей; розвиток здатності цінувати історичний досвід, економічні, культурні, соціальні традиції; спонукання до вироблення якостей, необхідних для позитивної взаємодії з партнерами і конкурентами різних національностей. Підсумковий етап має на меті узагальнення отриманих результатів і прогнозування подальших дій.

\section{V Висновки}

Таким чином, полікультурна компетентність майбутніх економістів передбачає знайомство 3 самобутніми етнічними національними рисами в культурі різних народів; залучення студентів до світової культури; розкриття процесу глобалізації, взаємозалежності країн і народів у сучасних умовах; визнання рівних прав і обов'язків представників інших народів та релігій; формування полікультурних компетенцій у межах їх просресійної компетентності.

Виділення у структурі полікультурної компетентності когнітивного, емоційно-ціннісного та поведінково-діяльнісного аспектів полікультурної толерантності та соціально-культурної ідентичності достатньо повно відображає необхідні для підготовки студентів-економістів до професійної діяльності у полікультурному середовищі якості особистості, знання, уміння і досвід, інтегративний характер формування комунікативної компетентності фахівців з економіки в умовах освітнього процесу 3ВО.

Реалізація педагогічних умов (створення розвивального полікультурного середовища;застосування інтерактивних методів полікультурної освіти;активізація креативності і дослідницької діяльності студентів)забезпечить успішність фрормування полікультурної компетентності майбутніх економістів.

Використання міжпредметних та міждисциплінарних зв'язків з точки зору етнопедагогічних і етнопсихологічних характеристик надає більш широкі можливості для інтеграції фахівця з економіки у полікультурне професійне середовище.

Сформованість полікультурної компетентності дозволить дипломованим фахівцям з економічного профілю здійснювати успішну професійну діяльність в умовах культурного розмаїття, застосовуючи 
навички гуманного міжнаціонального і міжкультурного спілкування; сприятиме гармонізації стосунків представників різних культур.

Перспективними напрямами подальших досліджень $є$ підготовка викладачів вищої школи до полікультурного виховання студентів.

\section{Бібліографічні посилання}

[1] Борисенков В. П. Вызовы современной эпохи и приоритетные задачи современной науки / Педагогика. 2004. № 1. C. 3-10.

[2] Гриньова В. М. Аксіологічний підхід до проблеми педагогічної культури майбутнього вчителя / Шлях освіти. 2002. № 2. C. 2-6.

[3] Давидов В. В. Проблемы развивающего обучения. М.: Академия, 2004. 240 c.

[4] Джуринский А. Н. Педагогика в многонациональном мире. М. : ВЛАДОС, 2010. 240 с.

[5] Кузьменко В. В., Гончаренко А. А. Формування полікультурної компетентності вчителів загальноосвітньої школи : навч. посіб. Херсон: РІПО, 2006. 92 с.

[6] Лукьянова М. И., Шустова Л. П. Моделирование процесса формирования поликультурной компетентности обучающихся в образовательной организации / Современные проблемы науки и образования. 2015. № 4.URL: http://www.science-education.ru/ru/article/view?id=21295 (дата звернення 01.03.2019).

[7] Набока О.Г. Професійно-орієнтовані технології навчання у фаховій підготовці майбутніх економістів: теорія та методика застосування: монографія. Слов'янськ: Підприємець Маторін Б. Г., 2012. 303 с.

[8] Новикова Л. А. Моделирование поликультурного образования учащихся. Профессиональное образование,2006. № 12, C. $17-19$

[9] Паламарчук Л. Б. Формування полікультурної компетентності в процесі підготовки майбутнього педагога / Акмеологія в Україні: теорія і практика: зб. наук. пр. К., 2013. № 24. С. 49-54

[10] Поясок Т. Б. Полікультурність у вищій економічній освіті / Проблема полікультурності у неперервній професійній освіті. Маріуполь: Маріупольський держ. ун-т, 2011. С. 66-70.

[11] Поясок Т.Б. Система застосування інформаційних технологій у професійній підготовці майбутніх економістів: монограффія. Кременчук: ПП Щербатих, 2009. 348 с.

[12] Різник В. Сучасна професійна підготовка студентів економічних спеціальностей у вищій школі як педагогічна проблема / Гуманітарний вісник: зб. наук. пр. Переяслав-Хмельницький держ. пед. ун-т імені Григорія Сковороди. 2009. № 17. С. $87-89$

[13] Соколова І. В. Феномен полікультурності в неперервній професійній освіті: соціокультурний і педагогічний контексти / Проблема полікультурності у неперервній професійній освіті. Маріуполь: Маріупольський держ. ун-т, 2011. С. 28-38

[14] Ткаленко Н. В., Федорченко В.В.Проблема підготовки сучасних економістів у системі вищої освіти України / Науковий вісник ЧДІЕУ. 2011. № 3(11). С. 31-35.

[15] Bachmann S., Yerhold S., Wessling Y. Aufgaben und Ubungstypologie zuminter kulturellen Lernen / Zielsprache Deutsh 27. Soestlandesinstitut fur Schule. 1996. P. 77-91

[16] Samovar L. A.,Poter R. E., McDaniel E. R. Communication betweencultures. Wadsworth Cengage Learning, 2010. 411 p.

\section{References}

[1] Borisenkov, V. P. (2004). Vyizovyi sovremennoy epohii prioritetnyie zadachi sovremennoy nauki. Pedagogika, 1, 3-10. [in Russian].

[2] Grinova, V. M. (2002). Aksiologichniy pidhid do problem pedagogichnoyi kulturi maybutnogo vchitelya. Shlyahosvlti, 2, 2-6. [in Russian].

[3] Davidov, V. V. (2004). Problemyi razvivayuschego obucheniya. Akademiya, Moscow, Russia, 240. [in Russian].

[4] Dzhurinskiy, A. N. (2010). Pedagogika v mnogonatsionalnom mire. VLADOS, Moscow, Russia, 240. [in Russian].

[5] Kuzmenko, V. V., Honcharenko, A.A. (2006). Formuvannia polikulturnoi kompetentnosti vchyteliv zahalnoosvitnoi shkoly: navch. posib. RIPO, Kherson, Ukraine, 92. [in Ukrainian]

[6] Lukyanova, M. I., Shustova, L. P. (2015). Formation process modeling polycultural competence of the trained in the educational organization. Modern problems of science and education, 4. URL: http://www.scienceeducation.ru/ru/article/view?id=21295 (accessed 01.03.2019). [in Russian].

[7] Naboka, O. H. (2012). Profesiino-oriientovani tekhnolohii navchannia u fakhovii pidhotovtsi maibutnikh ekonomistiv: teoriia ta metodyka zastosuvannia : monohrafiia. Pidpryiemets Matorin B. H., Sloviansk, Ukraine, 303. [in Ukrainian]

[8] Novikova, L. A. (2006). Modelirovanie polikulturnogo obrazovaniya uchaschihsya. Professional education, 12, 17-19 [in Russian].

[9] Palamarchuk, L. B. (2013). Formuvannia polikulturnoi kompetentnosti $\vee$ protsesi pidhotovky maibutnoho pedahoha. Akmeolohiia v Ukraini: teoriia i praktyka: zb. nauk. pr., 24, 49-54. [in Ukrainian]

[10] Poiasok, T. B. (2011). Multiculturalism in higher economic education. Problema polikulturnosti u neperervnii profesiinii osviti, 66-70. [in Ukrainian]

[11] Poiasok, T. B. (2009). Systema zastosuvannia informatsiinykh tekhnolohii u profesiinii pidhotovtsi maibutnikh ekonomistiv: monohrafiia. PP Shcherbatykh, Kremenchuk, Ukraine, 348. [in Ukrainian] 
[12] Riznyk V. (2009). Suchasna profesiina pidhotovka studentiv ekonomichnykh spetsialnostei u vyshchii shkoli yak pedahohichna problema. Humanitarnyi visnyk: zb. nauk. pr., 17, 87-89.[in Ukrainian]

[13] Sokolova, I. V. (2011). Fenomen polikulturnosti v neperervnii profesiinii osviti: sotsiokulturnyi i pedahohichnyi konteksty. Problema polikulturnosti u neperervnii profesiinii osviti, 28-38. [inUkrainian]

[14] Tkalenko, N. V., Fedorchenko, V. V. (2011) Problema pidhotovky suchasnykh ekonomistiv u systemi vyshchoi osvity Ukrainy. Naukovyi visnyk ChDIEU, 3(11), 31-35. [in Ukrainian]

[15] Bachmann, S., Yerhold, S., Wessling, Y.(1996). Aufgaben und Ubungstypologie zuminter kulturellen Lernen. Zielsprache Deutsh 27, Soestlandesinstitutfur Schule, 77-91. [in German]

[16] Samovar, L. A., Poter, R.E., McDaniel, E.R.(2010). Communication betweencultures. Wadsworth Cengage Learning, USA, 411.

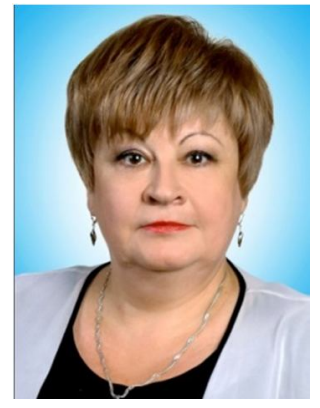

\section{Поясок Тамара Борисівна.}

Д. пед. н., професор, академік Української академії акмеології, декан факультету права, гуманітарних і соціальних наук, професор кафедри психології, педагогіки та філософії, Кременчуцький національний університет імені Михайла Остроградського, вул. Першотравнева, 20, м. Кременчук Полтавської обл., Україна, 39600.

Тел. +38(067) 269-78-96. E-mail: : poyasoktb@ukr.net

\section{Poyasok Tamara Borysivna,}

D.Sc. (Ped.), Professor, Full Member (Academician) Acmeology of The Ukrainian Academy, Dean of Faculty of Law, Humanities and Social Sciences, Professor of Pedagogy and Philosophy Department, Kremenchuk Mykhailo Ostrohradskyi National University, vul. Pershotravneva, 20, Kremenchuk, Poltava Region, Ukraine, 39600.

Tel. +38(067) 269-78-96.E-mail:poyasoktb@ukr.net

\section{ORCID:0000-0003-2818-6524}

Researcher ID:U-7618-2017

Scopus ID: 57202587392

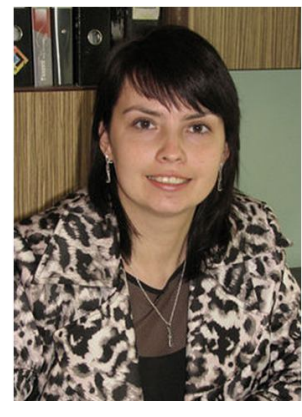

\section{Беспарточна Олена Іванівна.}

Канд. пед. наук, доцент, доцент кафедри психології, педагогіки та філософії, Кременчуцький національний університет імені Михайла Остроградського, вул. Першотравнева, 20, м. Кременчук Полтавської обл., Україна, 39600. Тел. +38(067) 798-05-39. E-mail: bespartochnay@ukr.net

\section{Bespartochna Olena Ivanivna,}

Cand. Sc. (Ed.), Associate Professor, Associate Professor of Pedagogy and Philosophy Department, Kremenchuk Mykhailo Ostrohradskyi National University,

vul. Pershotravneva, 20, Kremenchuk, Poltava Region, Ukraine, 39600.

Tel.+38(067) 798-05-39. E-mail:bespartochnay@ukr.net

ORCID: 0000-0001-8210-314x

Researcher ID: U-7547-2017

Scopus ID: 57202582754

\section{Citation (APA):}

Poyasok, T., Bespartochna, O. (2019). Forming polycultural competence for future economists. Engineering and Educational Technologies, 7 (1), 56-64. doi: https://doi.org/10.30929/2307-9770.2019.07.01.06

\section{Цитування (ДСТУ 8302:2015):}

Поясок Т. Б., Беспарточна О. І. Формування полікультурної компетентності майбутніх економістів / Інженерні та освітні технологіï. 2019. Т. 7. № 1. С. 56-64. doi: https://doi.org/10.30929/2307-9770.2019.07.01.06

Обсяг статmі: сторінок - 9 ; умовних друк. аркушів - 1,034 